\section{Prematüre buzağıların bakım ve tedavisine güncel}

yaklaşımlar

\section{Current approaches to the care and treatment of premature calves}

\section{ÖZET}

Buzağı ölümleri, Dünyada ve ülkemizde sığır yetiştiriciliğinin en önemli problemidir. Buzağı kayıpları, en yoğun perinatal ve neonatal dönemde yaşanır. Prematüre doğum, Dünyada ve Türkiye'de buzağı ölümlerinin önemli ve yaygın bir nedeni olmaya devam ediyor. Prematüre buzağılar, hastalıklara karşı oldukça duyarlı olduklarından özel bakıma ve tedaviye ihtiyaç duyarlar. Prematüre buzağı kayıplarının en önemli nedeni akciğer gelişim yetersizliğidir. Prematüre doğan buzağılarda akciğer gelişim yetersizliği sonucunda meydana gelen sürfaktan eksikliğinde akciğer yüzey gerilimi azaltılmaz, akciğerlerin hava ile dolumu yeterince sağlanamaz ve buna bağlı respiratorik distres sendrom (RDS) gelişir. Prematüre buzağılarda ölümün en önemli sebebi RDS'dir. Prematüre buzağıların tedavi ve bakımın zor olması ve prognozunun kötü olduğu anlayışından dolayı, prematüre buzağılar adeta ölüme terk edilmektedir. Oysa prematüre buzağıların doğru tedavi ve iyi bakımla hayatta kalma oranlarının oldukça yüksek olabileceği unutulmamalıdır. Bu derlemede, prematüre buzağıların doğru tedavisi ve iyi bakımı ile ilgili güncel ve deneyimsel bilgilerimiz bilim insanı ve klinisyenlerle paylaşı1mıştır.

Anahtar Kelimeler: Prematüre buzağı, RDS, tedavi, bakım

\section{ABSTRACT}

Calf death is the most important problem of cattle breeding in the world and in our country. Calf losses are most intense in the perinatal and neonatal period. Premature birth remains an important and common cause of calf mortality in the world and Turkey. The most important cause of premature calf losses is lung development failure. In the case of surfactant deficiency that occurs as a result of lung development failure in premature calves, lung surface tension is not reduced, air filling in the lung cannot be achieved sufficiently, and thus respiratory distress syndrome (RDS) develops. RDS is the most important cause of death in premature calves. Premature calves are almost left to die due to reasons such as the fact that treatment and care of premature calves are difficult and the prognosis is poor. Due to the understanding that treatment and care of premature calves are difficult and their prognosis is poor, premature calves are almost left to die. However, it should be kept in mind that the survival rate of premature calves with correct treatment and good care can be quite high. In this review, our current and experiential knowledge about the correct treatment and good care of premature calves was shared with scientists and clinicians.

Keywords: Premature calf, RDS, treatment, care

\section{How to cite this article}

Ok, M., İder, M., Kapar, MM., Yıldız, İK. (2021). Prematüre buzağıların bakım ve tedavisine güncel yaklaşımlar. Journal of Advances in VetBio Science and Techniques, 6(3), 331-342. https://doi.org/10.31797/vetbio.959012
Review Article

Mahmut $\mathrm{Ok}^{1 \mathrm{a}}$ Merve İder ${ }^{1 b}$

Muhammed Mustafa Kapar ${ }^{1 \mathrm{c}}$ İbrahim Kubilay Yıldız ${ }^{1 \mathrm{~d}}$

${ }^{1}$ Department of Internal Medicine, Faculty of

Veterinary Medicine, Selcuk University, Konya, Turkey

ORCID-

a0000-0002-8210-6735

b0000-0003-2928-5452

c0000-0002-8127-6994

d0000-0001-9052-6046

Correspondence

Mahmut OK

$\underline{\text { mok@selcuk.edu.tr }}$

Article info

Submission: 29-06-2021

Accepted: 23-11-2021

e-ISSN : 2548-1150

doi prefix: $10.31797 /$ vetbio

- $\underline{\text { http://dergipark.org.tr/vetbio }}$

This work is licensed under a Creative Commons Attribution 4.0 International License (c) (7) 


\section{İRIŞ̧}

Buzağı ölümleri, Dünyada ve ülkemizde sığır yetiştiriciliğinin en önemli problemlerindendir. Buzağı kayıpları, en yoğun perinatal ve neonatal dönemde yaşanır. Perinatal dönem; doğum öncesinde, esnasında veya doğumu takiben 48 saat içerisini kapsarken, neonatal dönem ise doğumdan sonraki ilk 28 günü kapsar (Çelik vd., 2016; Gundelach vd., 2009; Ok vd., 2009). Neonatal dönemdeki buzağı kayıplarının birincil sebebi ishalle seyreden hastaliklar, ikincil nedeni ise solunum yolu hastalığı oluştururken (Coskun vd., 2010; Ok vd., 2009; Ok vd., 2020; Sen vd., 2009), perinatal dönemdeki buzağı kayıpların birincil sebebi gelişimini tamamlamadan doğan prematüre buzağı, ikincil sebeplerini de yeni doğan buzağıya yeterince özenin gösterilmemesi, güç doğum, travma ve konjenital anomaliler oluşturur (Gundelach vd., 2009; Johanson ve Berger, 2003; Ok vd., 2020; Yıldız vd., 2017). Perinatal buzağı kayb1 ABD'lerinde \% 8-9 (Meyer vd., 2001), Avrupa ülkelerinde \% 10 (Johanson ve Berger, 2003) ve ülkemizde kesin veri olmamakla birlikte \% 12.7 (Çelik vd., 2016) civarında olduğu tahmin edilmektedir.

Prematüre ifadesi terminolojide erken ya da günsüz doğan anlamında kullanılır. Gebeliğin 260. gününden önce canlı doğan buzağılar prematüre olarak tanımlanır. İneklerde normal gebelik süresi tamamlanmadan gebeliğin 230260 günleri arasında gerçekleşen doğumlar "prematüre doğum", bu tür doğumlarda canlı olarak doğan buzağılar ise "prematüre buzağı" olarak tanımlanır (Altuğ vd., 2013; Aydoğdu vd., 2016; Güzelbekteş vd., 2012; Irmak ve Turgut, 2011; Kornmatitsuk vd., 2003; Ok vd., 2020; Ok, 2020; Y1ld1z vd., 2017).

$\mathrm{Bu}$ derlemenin yazılmasında temel amaç; son yıllarda prematüre doğan buzağıların bakım ve tedavisine güncel yaklaşımlar hakkında bilgileri bilim insanları ve klinisyenlerle paylaşmaktır.

\section{ETIYYOLOJİ}

Prematüre buzağı doğumlarının etiyolojisi tam olarak aydınlatılmamış olmasına rağmen birçok faktör ve değişik patolojik mekanizmalar etkili olabileceği ifade edilmektedir. Prematüre veya abort doğumlara başta enfeksiyöz hastalıklar (bakteriyel, viral, fungal ve protozoal) olmak üzere, fiziksel faktörler (hipotermi, hipertermi, hipoksi, travma), metabolik hastalıklar (tiroid bozuklukları), çevresel faktörler (toksik bitki tüketimi, bazı ilaç uygulamaları, mikotoksinler ve beslenme yetersizliği), hormonal faktörler (kortikosteroid, östrojen ve prostaglandin uygulamaları), canlı aşılar ve genetik faktörler (otozomal genler) yol açabileceği bildirilmektedir (Fluegel-Dougherty vd., 2013; Palmer vd., 1996; Radostits vd., 2007; Warner, 2009). Prematüre doğumların oluşum mekanizmasında plasentomların normal şekilde olgunlaşamamasından dolayı maternal karunkulaların fötal villuslardan ayrılması, enfeksiyöz nedenlere bağlı yangısal değişikliklerin plasentomlardaki maternal ve fötal dokuları birlikte etkilemesi, plasentomların dejenerasyonu ve villus nekrozu gibi faktörlerin etkili olabileceği rapor edilmiştir (Sheldon vd., 2004; Y1ldiz vd., 2017). Akut rumen asidozunda oluşan endotoksin ve metabolitlerin dolaşıma katılması (Altuğ vd., 2013; Radostits vd., 2007), şiddetli karaciğer yağlanması (Macfarlane ve Walker, 2007), protein, enerji, vitamin ve mineral madde yetersizliklerinin prematüre buzağ 1 doğumlarına yol açabileceği ortaya konmuştur (Radostits vd., 2007). Gül ve Baykalır (2013) prematüre buzağılarda $\beta$ karoten düzeyinin önemli oranda düşük olduğunu, $\beta$-karoten eksikliğinin prematüre doğuma yol açabileceğini bildirmişlerdir. Gebelik döneminde anneye uygulanan glikokortikoid ve prostaglandin $\mathrm{F}_{2} \alpha$ analogları, gebeliğin son döneminde sedasyonla yapılan tırnak kesimi ve nakillerin prematüre doğuma zemin hazırlayabileceği rapor edilmiştir (Bleul, 2009). 


\section{PATOGENEZ}

Prematüre buzağılar normal gelişim sürecini tamamlamadan doğdukları için solunum sistemi, gastrointestinal sistem, dolaşım sistemi, sinir sistemi ve metabolizmayla ilgili pek çok probleme sahip olabilirler (Aydoğdu vd., 2016; Bleul, 2009; Ok vd., 2020; Ok, 2020; Y1ldiz vd., 2017; Y1ldız vd., 2019). Prematüre doğan buzağılarda en önemli problem yetersiz akciğer gelişimidir. $\mathrm{Bu}$ durumda akciğerler, yeterince sürfaktan sentezleyemez. Akciğerde tip-II pnömositler tarafından salgılanan ve yapısı itibariyle \%90'ını lipidlerin oluşturduğu sürfaktan, akciğer yüzey gerilimini azaltan, akciğerlerin genleşmesini sağlayarak gaz alışverişini kolaylaştıran ve ödem oluşumunu engelleyen kompleks bir maddedir. Diğer bir değişle sürfaktan, akciğer alveollerinin ve bronşiollerin iç yüzünü örten sıvı film tabakası içinde bulunan ve bu sıvının yüzey gerilimini azaltan, tip-II pnömositlerin salgıladığı yüzey aktif maddelerine verilen genel isimdir. Özellikle fötal gelişime paralel olarak sürfaktan bileşimi değişiklik gösterir ve akciğeri doğum sonrası solunuma hazırlar (Ortatatlı ve Çiftci, 1996). Prematüre doğan buzağılarda akciğer gelişim yetersizliği sonucunda meydana gelen sürfaktan eksikliğinde akciğer yüzey gerilimi azaltılmaz, akciğerlerin hava ile dolumu yeterince sağlanamaz ve buna bağlı doğumdan sonra başlayan solunum güçlüğü, hırıltılı solunum ve inlemelerle karakterize olan respiratorik distres sendrom (RDS) gelişir. Premature buzağılarda ölümlerin en önemli sebebi respiratorik distres sendrom gelişimidir (Ok vd., 2020; Yıldız vd., 2017; Y1ldız ve Ok, 2017; Yıldız vd., 2019). Yeni doğan yavrularda sürfaktan yetersizliğinde pulmoner uyum bozukluğu sonucu hava değişiminde aksamalara ilişkin hipoksi, intersitisyel yangı, aşırı zorlanmaya bağlı pulmoner hipertansiyon ve intersitisyel ödem oluşur, tedavi edilmediği takdirde genellikle kısa süre içinde ölüm meydana gelir (Ok vd., 2020; Y1ldız vd., 2017; Yıldız ve Ok, 2017). Prematüre doğanlarda diğer bir problemde gastrointestinal sistem ile ilgili bozukluklardır. İntestinal motiliteyi konu alan çalışmalar, prematüre bebeklerin zamanında doğanlara göre bağırsak hipomotilitesine sahip olduğunu ve oral beslenmenin hipomotilitenin şiddetini arttırdığını göstermiştir. Güzelbekteş vd., (2012) prematüre buzağıların çoğunda gastroösefagiyal reflu geliştiğini ve mutlaka buna yönelik tedavi gerekliliğini vurgulamışlardır. Gelişimini tam olarak sağlayamayan preterm bebeklerde besinlerin yetersiz sindirimi ve geçiş zamanının uzaması yetersiz bağırsak bariyer savunması ile birlikte bağırsak hasarına neden olabileceği ifade edilmektedir. Y1ldı vd., (2019) yaptıkları çalışmada RDS'li prematüre buzağılarda fazla miktarda kolostrum verilmesinin RDS'yi şiddetlendirerek ölüm riskini arttırmanın yanında, bağırsaklara bası yaparak mikrosirkülasyonunu olumsuz etkileyerek bağırsak hasarı oluşturduğunu bağırsak hasar biyobelirteçleri ile tespit etmişler ve prematüre buzağılarda mümkünse kolostrumu az miktarda ve sık aralıklarla verilmesinin gerektiğini bildirmişlerdir. Ayrıca yine aynı araştırıcılar atresia kolili buzağılarda bağırsaklarda uzun süre biriken içeriğinin mikrosirkülasyon ve oksijenizasyonu bozarak hasarın neden olduğunu bağırsak hasar biyobelirteçleri ile ortaya koymuşlardır (Yıldız vd., 2018).

\section{KLIINIIK BULGULAR}

Prematüre buzağılarda yaygın olarak görülen fiziksel bulgular; düşük canlı ağırlık, kısa yumuşak tüylülük (Figür 1.), dişlerin diş etlerinden tam olarak sıyrılmaması (Figür 2.), ayak tırnaklarının yumuşaklığı (Figür 3.), halsizlik, emme refleksinin yetersiz olması ve solunum güçlügüdür (Güzelbekteş vd., 2012; Koterba ve Madigan, 1990; Ok vd., 2000; Ok vd., 2020; Ok, 2020; Y1ldiz vd., 2017). Bu bulgular içinde dikkat çeken en önemli klinik semptom kötüye giden ilerleyici bir solunum güçlüğü tablosudur. Prematüre buzağılarda solunum güçlüğüne ilişkin olarak abdominal 
solunum, hirılt1l solunum, inleme, burun kanatlarının açılması ve göz mukozasının kirli mavi renk (siyanoz) alması gibi semptomlar belirlenir. Tüm bu klinik bulgular prematürelerde respiratorik distres sendroma işaret eder (Ok vd., 2020; Y1ldız vd., 2017). Bunun yanında kolostrum tüketen buzağılarda abdominal gerginlik oluşumu söz konusu olursa bağırsak hareketlerin yeterince sağlanamadığ anlamına gelir.

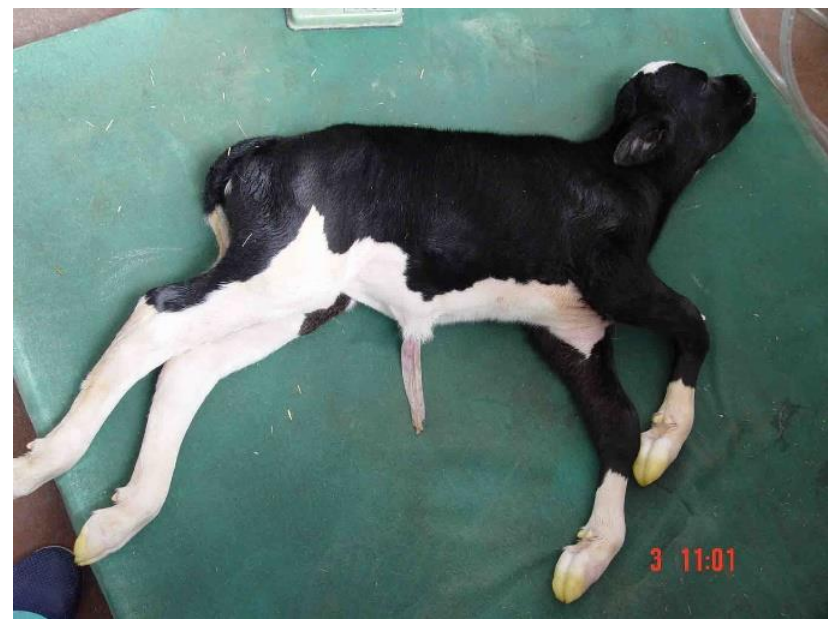

Figür 1. Kısa ve yumuşak tüylülük (Ok 2020).

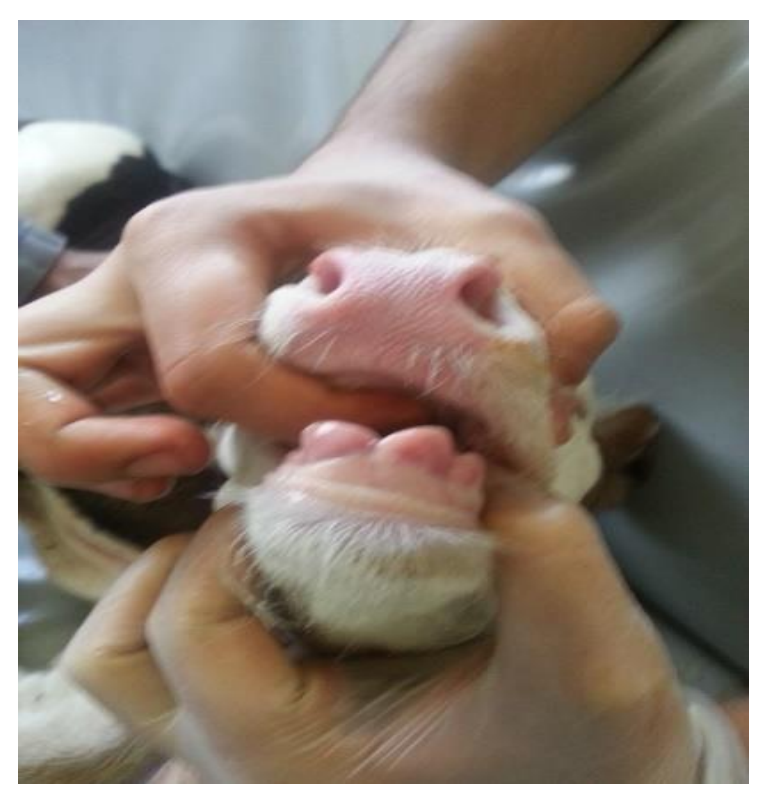

Figür 2. Diş etlerinden sıyrılmamış dişler (Ok 2020).

Respiratorik distres sendrom kriterleri;

- Respiratorik asidozis,

- Hipoksi $\left(\mathrm{PaO}_{2}<60 \mathrm{mmHg}\right)$,

- Hiperkapnia $\left(\mathrm{PaCO}_{2}>45 \mathrm{mmHg}\right)$,
- Takipne (Solunum sayıs1 >45/dk),

- Abdominal inlemeli ve/veya hirilt1l solunumdur (Bluel vd., 2008; Ok vd., 2020; Ok, 2020; Yildız vd., 2017).

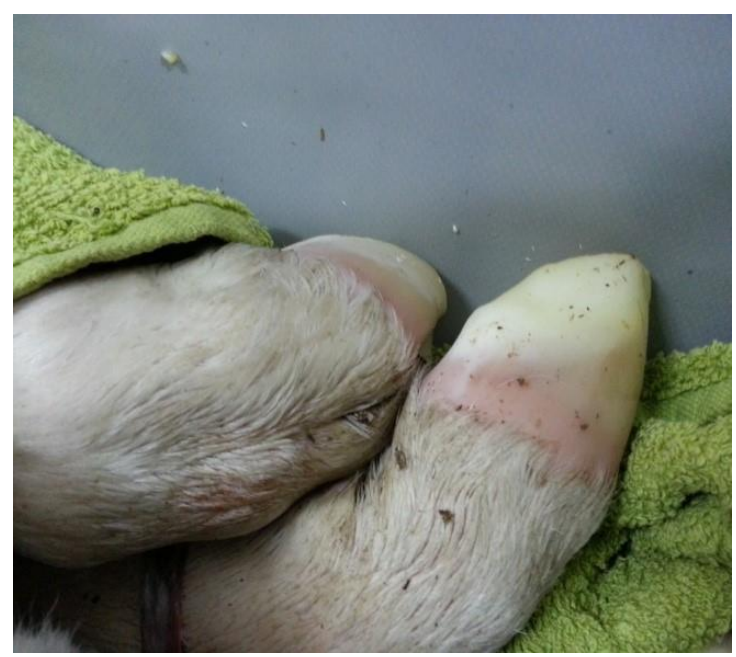

Figür 3. Yumuşak tırnaklar (Ok 2020).

\section{TESHIS}

Prematüre buzağıların teşhisi anamnez, klinik ve laboratuvar (kan gazı) bulgulara göre konur. Gebelik süresinin kısalığg, düşük canlı ağırlık, kısa yumuşak tüylülük, diş etlerinin dişlerden tam olarak sıyrılmaması, ayak tırnaklarının yumuşaklığı gibi klinik belirtiler RDS'siz prematüre buzağı olduğunu gösterirken (Koberte vd., 1990; Ok vd., 2020; Ok, 2020; Y1ldız vd., 2017; Y1ldız vd., 2019), RDS'li prematüre buzağılarda ise yukarıda sözü edilen klinik bulgulara ilave olarak takipne (solunum sayıs1 $>45 / \mathrm{dk}$ ), abdominal solunum, ekspiratuvar inleme, inspirasyon sirasinda sternum, interkostal kaslar ve alt kostaların içeri doğru çekilmeleri, burun kanatlarının solunuma katılması gibi fiziksel bulgular ve respiratorik asidoz, hipoksi $\left(\mathrm{PaO}_{2}<60 \mathrm{mmHg}\right)$, hiperkapnia $\left(\mathrm{PaCO}_{2}>45 \mathrm{mmHg}\right)$, hiperlaktatemi gibi laboratuvar bulgular gözlemlenir (Bluel vd., 2008; Ok vd., 2020; Ok, 2020; Y1ld1z vd., 2017; Y1ld1z vd., 2019).

\section{TEDAVII VE BAKIM}

Prematüre buzağılar, en fazla bakıma ve özene ihtiyaç duyan yavrulardır. Doğduklarında başta akciğer olmak üzere, sindirim sistemi, sinir 
sistemi, karaciğer ve böbrek gibi bazı organlar yeterince gelişmemiş olabildiğinden hastalıklara karşı önemli hassasiyetleri vardır (Bleul, 2009; Ok vd., 2020; Y1ldız vd., 2007; Y1ldız vd., 2019). Prematüre buzağılarda ilk yapılacak işlemler aşağıda sunulmuştur.

\section{A. Prematürre buzağıllarda bakım}

Ilk yapılacak işlem buzağının üst solunum yollarının temizlenerek solunum yapmasını sağlamak

Prematüre buzağ 1 doğumlarında ilk etapta elektrikle çalışan veya manuel vakumlu pompalarla burun, ağız ve farenksteki mukus temizlenmelidir. Basit pompa işlemi ile solunum yolunda biriken sivi ve mukuslar uzaklaştırılabilir ya da sıvının akmasını sağlayacak kadar (en fazla 1 dakika) buzağı arka bacaklardan başı aşağıya gelecek tarzda asilabilir (Bleul, 2009; Ok vd., 2020; Uystepruyst vd., 2002; Y1ld1z vd., 2017). Bu işlemin uzun tutulmamasının nedeni, interkostal kasları tam olarak gelişmeyen prematüre buzağının solunum yükünün çok fazla olduğu ve bu yükü diyaframla kompanze etmeye çalıştı̆̆ oraya yapılacak uzun süreli baskıların solunumun kötüye gitmesine neden olabileceğidir. Yukarıda sözü edilen uygulamalarla solunumunu başlatılamayan prematüre buzağılara solunum merkezini uyarmak için başın arkasına soğuk su dökme, burun kanatlarını çimdikleme ya da solunum uyarıcı ilaçlar (doksapram, lobelin vb.) yapılmalıdır (Divers, 2008; Ok vd., 2020; Y1ldız vd., 2017; Zerbe vd., 2008).

\section{Prematüre doğan yavruların çoğunluğunda vücut ısısı düşük, yani hipotermiktir}

Prematüre buzağıların hipotermik olup olmadığ 1 derhal belirlenmelidir. Hipotermi, termometre ile vücut 1sısı $\left(<35 \mathrm{C}^{\circ}\right)$ ölçülerek belirlenebildiği gibi, termometre olmadığı zaman ağız sıcaklığına göre de belirlenebilir. Prematüre buzağılar doğum sonrası hipotermiye karşı vücut 1sılarını normal sınırlarda tutmak için çok fazla enerji harcamaktadırlar. Bu durum kahverengi yă dokusundan yoksun olan prematüre buzağılarda ciddi enerji eksikliğine zemin hazırlayacaktır. Normal buzağılar, vücut 1sılarını normal seviyelere çekmeyi başarırlarken, prematüre buzağılar başaramazlar, hipotermi devam eder, bundan dolayı vücut önemli zarar görür. Prematüre buzağılarda enerji sarfiyatını en aza indirmek ve hayat1 tehdit eden hipotermiden zarar görmemesi için, buzağının bulunduğu yerdeki soğuk cisimler ve altlıklar uzaklaştırılmalı, hava sirkülasyonu riski azaltılmalı, buzağı en kısa sürede havlu veya saç kurutucu ile kurutulmalıdır (Figür 4.).

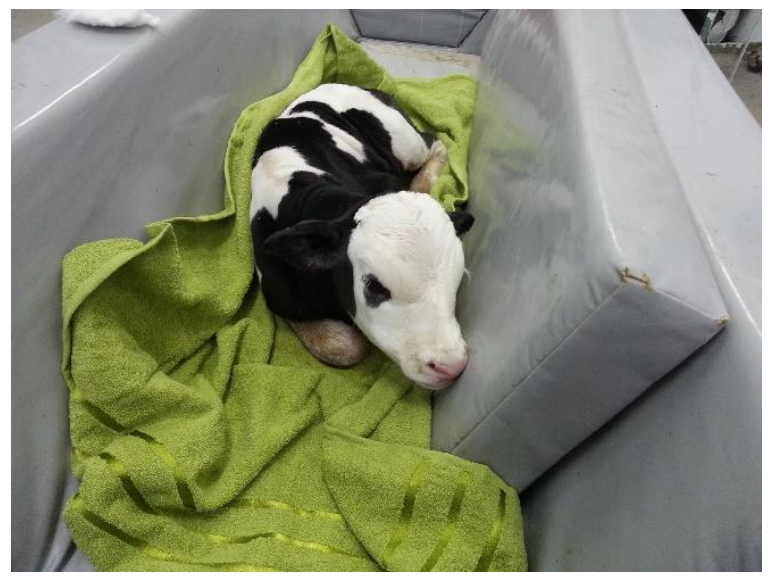

Figür 4. Havlu ile tüylerin kurutulması (Ok 2020).

Prematüre buzağılar özel odaya alınmalı, oda 1sitıcilarla 1sitılmalı (Figür 5.) ve vücut 1sisı normal düzeye gelinceye kadar buzağının üzeri havlu veya battaniye ile örtülmelidir.

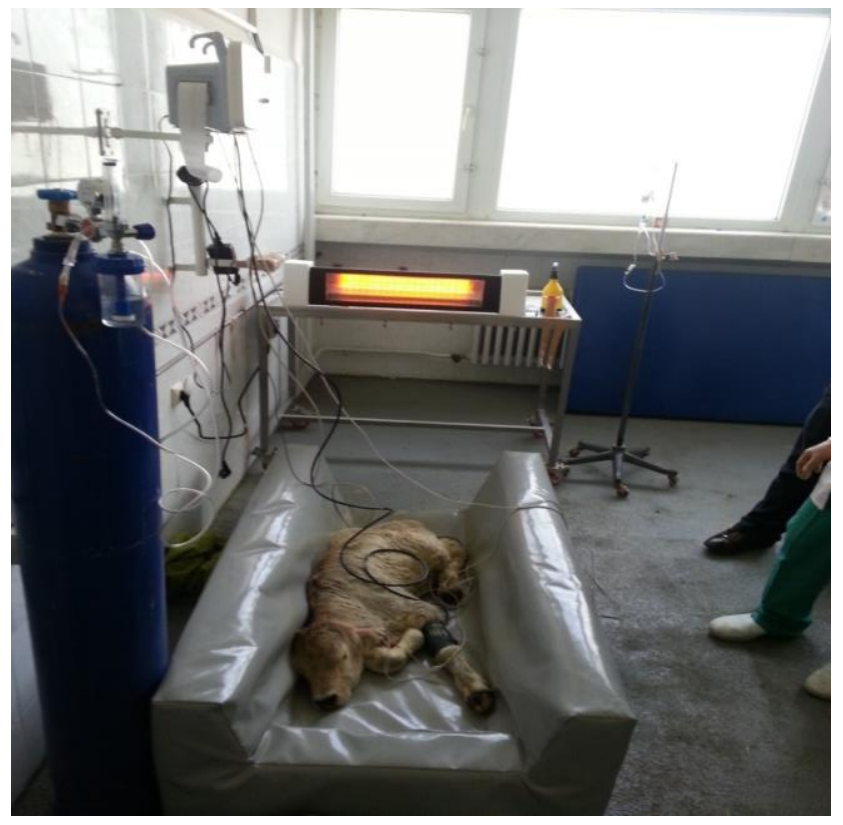

Figür 5. Odanın 1sitıc1 ile 1sitılmas1 (Ok 2020). 
Prematüre buzağılar, özel odada en az 3-4 gün tutulmalıdır. $\mathrm{Bu}$ süre içinde özel oda günde bir kez dezenfekte edilmelidir (Bluel vd., 2009; Lammoglia vd., 1999; Ok vd., 2020; Satar, 2004; Uystepruyst vd., 2002; Y1ld1z vd., 2017).

\section{Prematüre buzağıların solunumunun düzenli hale getirilmesi}

Soluk alışverişinin daha rahat sağlanabilmesi için buzağı sternal, yani göğüs üzeri pozisyonda tutulmalıdır (Figür 6.).

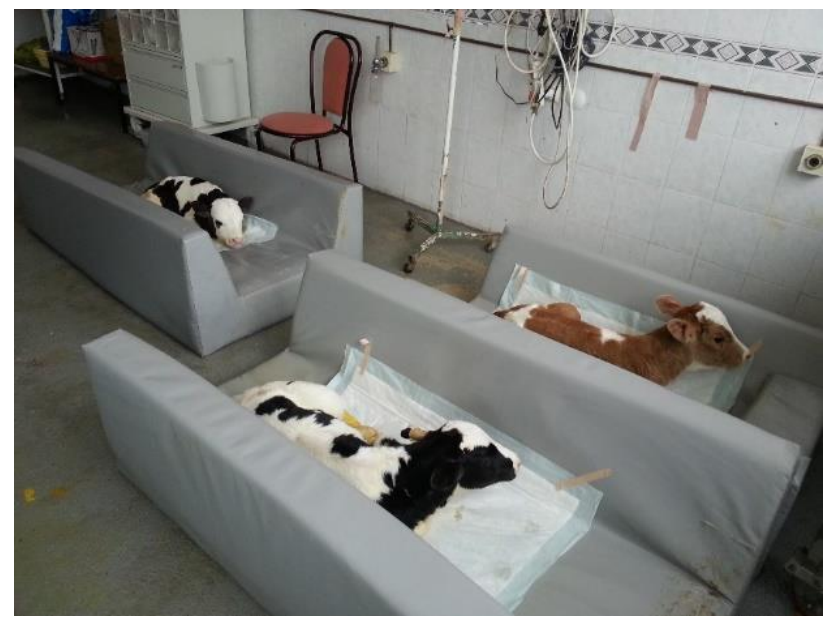

Figür 6. Buzağıların özel yatakta göğüs üzerinde tutulması (Ok 2020).

Göğüs üzeri pozisyonda yatan buzağıların, sağ veya sol yan pozisyonda yatanlara göre gögüs, diyafram ve akciğerlerinin daha az stres altında kaldığ1, soluk alışverişinin daha rahat yapıldığ ve daha iyi oksijen karbondioksit değişiminin olduğu belirlenmiştir (Yıldız vd., 2017; Yıldız vd., 2019; Ok vd., 2020). Bu nedenle prematüre buzağıların göğüs üzeri pozisyonda tutulması önerilmektedir. Prematüre buzağıları göğüs üzeri pozisyonda tutmanın en önemli yolu özel tasarlanmış yatakla olur (Figür-6). Şayet bu pozisyonda tutmak mümkün değilse, kısa aralıklarla pozisyonun sağa-sola değiştirilmesinde fayda vardır (Bluel vd., 2009; Uystepruyst vd., 2002). Bizim çalışmalarımızda da RDS'li prematüre buzağılarda göğüs üzerine yatırılanlarda (Figür 6.) solunumun düzenli hale geldiği, RDS bulgularının ortadan kalktığı ve buzağıların hızla iyileştiğini gözlemledik (Ok vd., 2020; Y1ldız vd., 2017; Y1ldız vd., 2019).
Prematüre buzăğllara solunum desteği ve oksijen uygulaması yapılmalıdır

Prematüre buzağılarda solunum desteği çok önemlidir. Solunum desteği, oksijen uygulamasından mekanik ventilasyona kadar değişmektedir. Oksijen, hayat için vazgeçilmez bir maddedir, ancak aynı zamanda doğadaki en toksik maddelerden biridir. Tüm canlılarda antioksidan sistemlerin bulunmas1, oksijenin toksik etkilerine karşı konulması için var olan en ciddi önlemdir. Oksijen tedavisinin temel amacı; doku hipoksisini önleme veya azaltma, solunumu kolaylaştırma ve kalp stresini minimuma indirgemektir (Figür 7.).

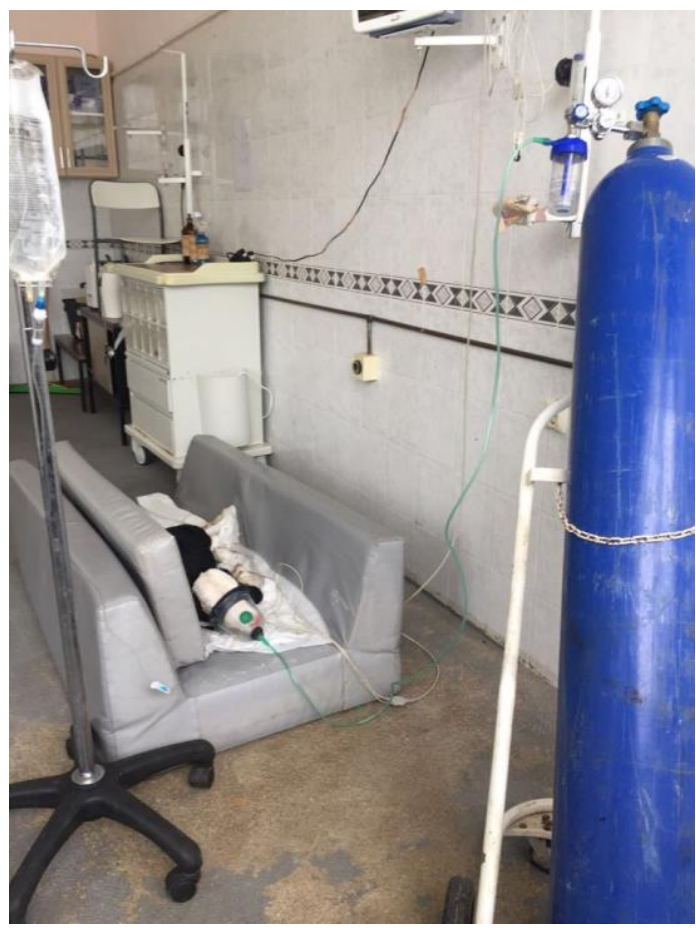

Figür 7. Prematüre buzağıya oksijen tedavisi (Ok 2020).

Diğer bir deyişle, $\mathrm{PaO}_{2}{ }^{\prime} 180 \mathrm{mmHg}$ civarında tutabilecek minimum oksijen miktarını hastaya vermektir (Figür 8.) (Bleul, 2009; Oval1, 2007; Ok vd., 2020; Y1ldız vd., 2017).

\section{Prematüre buză̆llarda diğer bir problem hipoglisemidir}

Hipoglisemi kan şekerinin düşük olmasıdır. Prematüre buzağılarda kan glikoz düzeyi çoğunlukla $\quad 30 \quad \mathrm{mg} / \mathrm{dL}$ 'nin altındadır. Hipoglisemik buzağılarda sinirsel bulgular ortaya çıkar. Hipoglisemiyi ortadan kaldırmak için damar içi yolla glikoz verilmesi gerekir. 
Ayrıca glikozla birlikte B vitamin uygulanması glikozun hızlı enerjiye dönüşüp organizmada kullanılmasına yardımc1 olur (Ok vd., 2020; Y1ld1z vd., 2017; Y1ld1z vd., 2019).

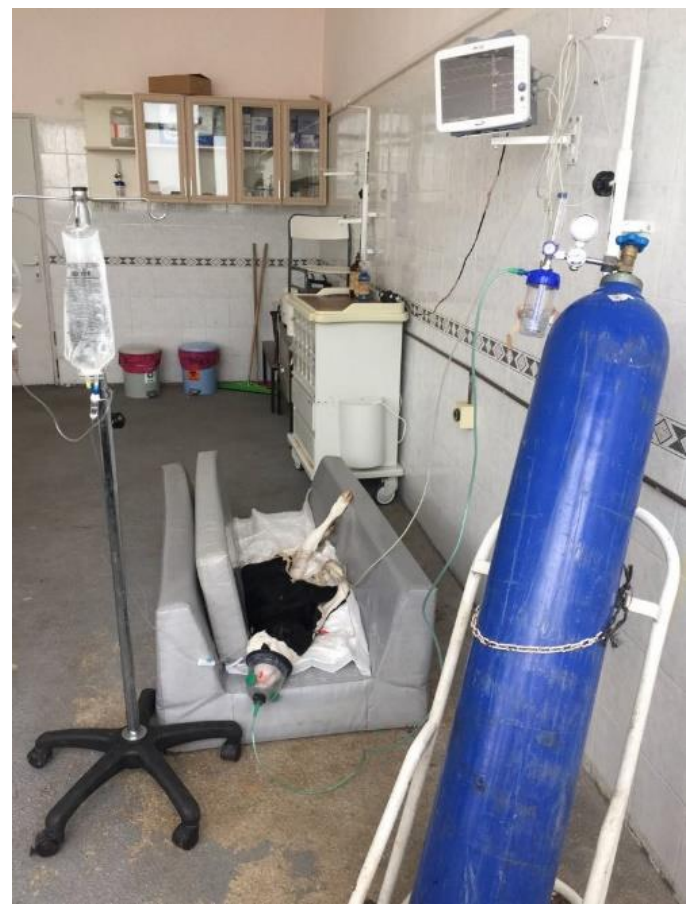

Figür 8. Oksijen tedavisi (Ok 2020).

\section{Prematüre buzağıların beslenmesi}

Prematüre buzağıların beslenmesi çok zordur ve fazla özen gösterilmesi gereken bir durumdur. Prematüre buzağıların genelinde emme refleks yetersizliği söz konusu olduğundan anne memesini veya biberonu ememezler. Bu yüzden, buzağılarda emme refleks kontrolü yapılmalıdır. Emme refleks kontrolünde buzağının ağzına parmakları soktuğunuzda, parmakları emmeye çalışması refleksin olduğu anlamına gelir. Emme refleksi olan buzağılara biberonla kolostrum (ağız sütü) verilebilir. Kolostrum buzağılara emme refleksi oluşuncaya kadar sonda ile emme refleksi oluştuktan sonra biberonla verilmelidir. Buzağılara verilecek kolostrum miktarı 500 mL'yi geçmemelidir. 6 saat arayla $500 \mathrm{~mL}$ kolostrum verilmelidir. Bir öğünde $500 \mathrm{~mL}$ 'den fazla kolostrum verildiğinde karın şişliğine ve solunum güçlüğüne neden olarak ölüme sebebiyet verebileceği unutulmamalıdır (Ok vd., 2020; Y1ld1z vd., 2017; Y1ld1z vd., 2019).
B. Prematüre buzağılara uygulanabilecek standart tedavi ve özel tedaviler

\section{Standart tedaviler}

Prematüre buzağıların standart tedavisi çoğunlukla destek tedaviden ibarettir. Destek tedavi olarak mineral ve vitamin, antibiyotik ve sivi-elektrolit anormalliklerinde parenteral siv1 verilir. Mineral ve vitamin olarak kalsiyum, fosfor, selenyum, A, B, C, D ve E vitaminleri uygulanabilir. Kalsiyum, fosfor, $\mathrm{C}$ ve $\mathrm{B}$ vitaminleri günde bir kez 3 gün süreyle, selenyum ve A, D, E vitamini bir kez kas içi uygulanabilir. Özellikle prematüre buzağıların çoğunluğunda gaströzefagiyal reflü belirlenmiştir (Güzelbekteş vd., 2012). Bu yüzden, reflüye yönelik $10 \mathrm{mg} / \mathrm{kg}$ dozunda eritromisin günde bir $\mathrm{kez}, 5 \mathrm{mg} / \mathrm{kg}$ raniditin günde iki kez 3-5 gün süreyle uygulanmasında fayda vardır. RDS'li prematüre buzağılarda kan gazı analizlerinde çoğunlukla miks asidozis ve hipoglisemi belirlenir. Bu yüzden, miks asidozis durumunda sıv1 solüsyonu olarak 250-500 mL \% 1,3'lük $\mathrm{NaHCO}_{3}$ 'll veya laktat ringerli serumlar tercih edilmelidir. Hipoglisemik buzağglarda 100-250 mL \%5'lik dekstroz uygulamas1 oldukça başarılı sonuç vermektedir (Çorum vd., 2019a; Çorum vd., 2019b; Ok vd., 2020; Yıldız vd., 2017; Y1ld1z vd., 2019).

\section{Akciğere yönelik özel tedaviler}

Respiratorik distres sendromlu prematüre buzağılarda en etkin tedavi, akciğerin iyileşmesine yönelik yapılan özel tedavidir. Akciğere yönelik tedavinin temel amacı; akciğer gelişimini sağlamak, dokuların gaz alışverişini kolaylaştırmak, solunumun devamlı ve düzenli hale gelmesini sağlamaktır. Akciğer yönelik tedavi, oksijen tedavisi ve inhaler tedaviden oluşur. Oksijen tedavisi hipoksemiyi ortadan kaldırmak oldukça etkilidir. İnhaler tedavi ise akciğerin gelişimini ve yangıyı ortadan kaldırarak gaz alışverişini kolaylaştırmak ve solunumu düzenli hale getirmede oldukça faydalı bir tedavi yöntemidir. Akciğerin gelişimine ve yangıyı ortadan kaldırarak gaz 
alışverişini kolaylaştırmak amacıyla sürfaktan veya inhaler bronkodilatatörler, yangı ve ödem gidericiler kullanılır (Bleul, 2009, Ok vd., 2020, Oval1, 2007, Pekcan, 2012, Y1ldız vd., 2017).

\section{Sürfaktan tedavisi}

Beşeri hekimlikte RDS'li prematüre doğan bebeklere ekzojen sürfaktan tedavi veya profilaktik amaçlı kullanılmaktadır. Sentetik ve doğal formları bulunan sürfaktan RDS dışında mekonyum aspirasyon sendromu gibi başka hastalıklarda da kullanılabilmektedir. Sürfaktan endotrakeal tüp içine yerleştirilen sonda aracılığgyla veya endotrakeal tüpün proksimal ucuna yerleştirilmiş bir adaptör yardımı ile prematüre yavrunun akciğerine uygulanmaktadır (Kültürsaray ve Tansuğ, 2000; Yurdakök, 1991). Beşeri hekimlikte RDS'li prematüre bir bebeğin tedavisinde kullanılan sürfaktan maliyeti 5.00010.000 dolar civarındadır, bu yüzden Veteriner Hekimlikte ticari sürfaktan preparatlar ekonomik olmadığından kullanılma şansı yoktur (Altuğ vd., 2013, Y1ld1z vd., 2017). Veteriner hekimlikte kesilen genç sığır akciğerlerinden elde edilen sürfaktan maddeleri kullanılabileceği ifade edilmektedir. Karapınar vd., (2008) kesim sonrası genç sığır akciğerlerinden elde ettikleri sürfaktan ekstresini sternal pozisyonda yatan RDS'li prematüre buzağılara $100 \mathrm{mg} / \mathrm{kg} / \mathrm{CA}$ dozunda intratrakeal uygulamışlar ve başarılı sonuç elde ettiklerini bildirmişlerdir.

\section{Inhaler tedavi}

Beşeri hekimlikte respiratorik distres sendromlu hastalarda inhaler ilaç uygulamaları akciğer fonksiyonunun k1sa sürede normale dönmesine önemli katkı sağladığı ortaya konmuştur. Bronkodilatatörler, yang1 gidericiler, diüretikler ve antibiyotikler inhaler yolla kullanılmaktadır. Nebulizasyon (inhalasyon) siv1 durumdaki ilacın, nebülizatör aracılığıyla buharlaştırılarak solunum yollarına verilmesi işlemine denir (Pekcan, 2012). Veteriner hekimlikte inhaler ilaçlar at ve pet hekimliğinde kullanılmakla birlikte çiftlik hayvan hekimliğinde kullanımı oldukça sınırlıdır. Yapmış olduğumuz çalışmalarda (Ok vd., 2020, Yıldız vd., 2017) RDS'li prematüre buzağıların tedavisinde nebulizer yolla bronkodilatatörler, yang1 gidericiler ve diüretik uygulamalarının başarılı (\%70-78) sonuç verdiğini belirledik (Figür 9.).

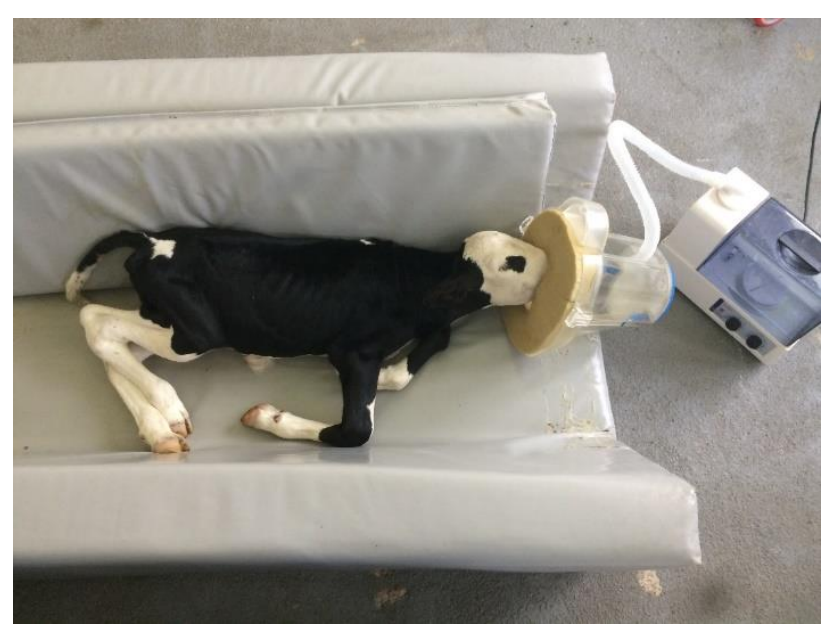

Figür 9. RSD'li prematüre bir buzağıya nebulizer cihazı ile inhaler ilaç verilmesi (Ok 2020).

RDS prematüre buzağılarda inhaler kullanılan ilaçların bir buzağı için maliyeti yaklaşık 6-7 dolar civarında olması oldukça ekonomik olduğu göstermiştir. Son y1llarda hem beşeri hem de veteriner hekimlikte inhalasyon yoluyla ilaç kullanımı, lokal ve hızlı etki sağlamanın yanı sıra, sistemik yan etkilerinin azlığı nedeniyle akciğer hastalıklarının tedavisinde kullanım alanı gittikçe artmıştır. İnhaler uygulamanın non-invaziv, kısa sürede etkinin başlaması ve düşük dozlarda etkili olması oral veya parenteral yolla uygulamaya göre en önemli avantajıdır (Ok vd., 2020, Pekcan, 2012, Y1ldiz vd., 2017). Bununla birlikte inhaler yolla verilen ilaçlar, yan etkilerinden uzak durularak hızlı şekilde ve istenilen miktarda akciğere ulaşmaktadır. İnhaler yolla verilen bronkodilatatörlerin 5 dakika içinde etkinliği başlayıp 15-30 dakika içinde pik seviyeye ulaşırken, oral uygulamalarda ilacın pik seviyeye ulaşması 2-3 saat almaktadır (Duvivier vd., 1997).

İnhaler olarak verilen kortikosteroid, bronkodilatatör ve diüretikler, akciğerdeki yangı, bronş kasılmalarını ve ödemi çözerek gaz alışverişi kolaylaştırarak solunum fonksiyonunun hızla normale dönmesi sağlar. İnhaler yolla bronkodilatatör olarak $\beta_{2}$ adrenerjik 
agonistler ve antikolinerjikler kullanılır, $\beta_{2}-$ agonisti bronkodilatatörler, kısa ve uzun etki göstermesine göre iki gruba ayrılır. Kısa etki gösterenler; metaproterenol, salbutamol, terbutalin ve fenoterol grubu bronkodilatatörlerdir. Uzun etkili $\beta_{2}$-agonisti bronkodilatatörlerin en yagin kullanılanı salmeterol ve formeteroldur (Barnes, 2008; Traş vd., 2012). Kortikosteroidler, solunum yolu hastalıklarında nebulizasyon yoluyla sıklıkla kullanılmaktadır. Nebulizer yöntemle uygulanan kortikosteroidler; sürfaktan üretimini artırmanın yanında, akciğer hasarında yangıyı azaltma, bronşiyal ve pulmoner ödemi azaltarak hastanın solunumunu düzenleyerek iyileşmesine katk1 sağlamaktadır (Traş vd., 2012; Yıldız vd., 2017). Kortikosteroidler, akciğer hastalıklarında yangıyı azaltma, antioksidant enzim ve sürfaktan üretimini artırma, bronşiyal ve pulmoner ödemi azaltma amaciyla kullanılmaktadır (Bancalari vd., 2005). Steroidlerin inhalasyon yoluyla kullanılması, sistemik kullanımlarda ortaya çıkan yan etkileri minimuma indirmektedir. Flutikazone propiyonat, beklametazone dipropiyonat, triamskinolon, budosenid, flunisolid gibi steroidlerin inhaler formları bulunmaktadır (Mazzaferro, 2006; Robinson vd., 2009). Bu ilaçlar içinde flutikazon propiyonatın terapötik etkisi en yüksekdir (Barnes, 1998). Tayların solunum yolu hastalıkları ve atların astım hastalığındainhaler kortikosteroid, bronkodilatatör, antibiyotik ve mukolitik uygulamışlar ve başarılı sonuç elde etmişlerdir (Leclere vd., 2010; Morresey, 2008). İnhaler yolla uygulanan bir ilaç grubu da diüretiklerdir. Diüretikler, akciğerin intersitisyel ödemini azaltmak, pulmoner vasküler direnci düşürmek (hipertansiyonu azaltma), gaz değişimini kolaylaştırmak ve akciğer hücreleri oksijen tüketimini azaltıp, oksijenin dolaşıma geçişini artırmak amacıyla kullanılmaktadır (Abman ve Groothius, 1994). Bu amaç için en yaygın kullanılan diüretik furosemittir (Ok vd., 2020; Y1ld1z ve Ok, 2017). Yildız ve Ok, (2017) ve Ok vd., (2020) RDS'li prematüre buzağılara inhaler yolla bronkodilatatör (salbutamol, formeterol) kortikosteroid (flutikazon, budesonid) ve diüretik (furosemid) uygulamışlar ve tedavide oldukça başarılı sonuç almışlardır.

\section{İlaçların inhalasyon dozu}

- Flutikazon'un nebulizer formu, $15 \mu \mathrm{g} / \mathrm{kg}$ dozunda $2.5 \mathrm{~mL}$ serum fizyolojik solüsyonu ile sulandırılarak 12 saat arayla 3 gün süreyle nebulizasyon yöntemi ile 5 dakika içinde uygulanır (Ok vd., 2020; Y1ldiz vd., 2017).

- Budesonid'in nebulizer formu nebulizasyon yöntemi ile $400 \mu \mathrm{g}$ total doz $2,5 \mathrm{~mL}$ serum fizyolojik solüsyonu ile sulandırılarak 12 saat arayla 3 gün süreyle 5 dakika içinde uygulanır.

- Salbutamol'un nebulizer formu $0.025 \mathrm{mg} / \mathrm{kg}$ dozunda 6 saat arayla 2,5 mL serum fizyolojik solüsyonu ile sulandırılarak 3 gün süreyle nebulizasyon yöntemi ile 5 dakika içinde uygulanır (Yıldız vd., 2017).

- Formoterol'un nebulizer formu $12 \mu \mathrm{g}$ total dozda 12 saat arayla $2.5 \mathrm{~mL}$ serum fizyolojik solüsyonu ile sulandirılarak 3 gün süreyle nebulizasyon yöntemi ile 5 dakika içinde uygulanır (Morresey, 2008; Ok vd., 2020).

- Furosemid'in parenteral formu $1 \mathrm{mg} / \mathrm{kg}$ dozunda $2.5 \mathrm{~mL}$ serum fizyolojik solüsyonu ile sulandırılarak 12 saat arayla 3 gün süreyle nebulizasyon yöntemi ile 5 dakika içinde uygulanır (Ok vd., 2020; Sahni ve Phelps, 2011; Y1ld1z vd., 2017).

\section{Oksijen desteği}

Solunum sistemi hastalıklarının tedavisinde en önemli katkıyı oksijen tedavisi sağladığ unutulmamalıdır. Yapmış olduğumuz çalışmalarda (Ok vd., 2020; Yıldız vd., 2017) respiratorik distres sendromlu prematüre buzağılara oksijen uygulamasının tedaviye ciddi katkı sağladığını müşahede ettik. Hastanelerde kurulan oksijen ünitelerinde oksijen ve karbondioksit belirli oranlarda olduğundan insan ve hayvanlara sürekli oksijen verilebilmektedir. Şayet bu ünite mevcut değilse, sanayi tipi oksijen 
tüpünden faydalanılabilir. Sanayi tipi oksijen tüpündeki oksijen buzağılara uygun oksijen maskesi (Figür 7.; Figür 8.) yardımı ile verilebilir. Buzağılara oksijen başlangıç olarak 5-6 L/dk akış hızıyla intranazal olarak 15'er dakika süreyle uygulanır, her uygulamadan sonra 10 dakika ara verilir. Her uygulamadan sonra 10 dakika ara verilmesinin nedeni saf oksijenin yoğun verilmesi toksik etki göstermesidir. $\mathrm{Bu}$ uygulama yaklaşık 3 saat kadar sürdürülür. Üç saat sonra oksijen akış hızı 3-4 L/dk'ya düşürülür. Oksijen tedavisine birkaç gün belirli aralıklarla devam edilebilir. Oksijen tedavisine son verilmesi şartı arteriyel $\mathrm{SatO}_{2}$ düzeyinin $>\% \quad 80 \mathrm{mmHg}$ üzerine çıkmış olmasıdır (Bleul, 2009; Korkmaz, 2003; Ok vd., 2020; Palmer vd., 1996; Y1ldız vd., 2017).

\section{AÇIKLAMALAR}

Çıkar çatışması: Yazarlar, bu makale için gerçek, potansiyel veya algılanan bir çıkar çatışması olmadığını beyan etmektedirler.

\section{KAYNAKLAR}

Abman, S. H., Groothius, J. R. (1994). Pathophysiology and treatment of bronchopulmonary dysplasia. Pediatric Clinics of North America, 41(2), 277-315. doi: 10.1016/s0031-3955(16)38726-0.

Altuğ, N., Basbuğan, Y., (2013). Premature buzağ1. Turkiye Klinikleri Journal of Vet erinary Sciences, 4(1), 53-61.

Aydogdu, U., Yildiz. R., Guzelbektes, H., Coskun, A., Sen, I. (2016). Cardiac biomarkers in premature calves with respiratory distress syndrome. Acta Veterinaria Hungarica, 64(1), 38-46. doi: 10.1556/004.2016.004.

Bancalari, E., Wilson-Costello, D., Iben, S. C. (2005). Management of infants with bronchopulmonary dysplasia in North America. Early Human Development, $\quad 81(2), \quad 171-9 . \quad$ doi: 10.1016/j.earlhumdev.2004.12.005.

Barnes, P. J. (1998). Current issues for establishing inhaled corticosteroids as the antiinflammatory agents of choice in asthma. The Journal of Allergy and Clinical Immunology, 101(4-2), 427-33. doi: 10.1016/s0091-6749(98)70154-x.

Bleul, U. (2009). Respiratory distress syndrome in calves. The Veterinary Clinics of North America. Food Animal Practice, 25(1), 179-93. doi: 10.1016/j.cvfa.2008.10.002.

Coskun, A., Şen, I., Guzelbektes, H., Ok, M., Turgut, K., Canikli, S. (2010). Comparison of the effects of intravenous administration of isotonic and hypertonic sodium bicarbonate solutions on venous acid-base status in dehydrated calves with strong ion acidosis. Journal of the American Veterinary Medical Association, 236(10), 1098-103. doi: 10.2460/javma.236.10.1098.

Çelik, E., Sen, I., Güzelbekteş H. (2016). Konya'nın Akşehir, Ilgın ve Kadınhanı İlçelerindeki perinatal buzağ1 mortalite prevalansı. Manas Journal of Agriculture Veterinary and Life Sciences, 6(2), 22-28.

Çorum, O., Altan, F., Yıldız, R., İder, M., Ok, M., Üney, K. (2019a). Pharmacokinetics of enrofloxacin and danafloxacin in premature calves. Journal of Veterinary Pharmacology and Therapeutics, 42(6), 624-31. doi: 10.1111/jvp.12787.

Çorum, O., Yıldız, R., İder, M., Altan, F., Ok, M., Üney, K. (2019b). Pharmacokinetics and bioavailability of cefquinome and ceftriaxone in premature calves. Journal of Veterinary Pharmacology and Therapeutics, 42(6), 632-39. doi: $10.1111 /$ jvp. 12789.

Divers, T. J. (2008). Diseases of dairy cattle (2nd ed.). Saunders Elsevier.

Duvivier, D. H., Votion, D., Vanden, P. S., Lekeux, P. (1997). Aerosol therapy in the equine species. Veterinary Journal, 154(3), 189-202. doi: 10.1016/s1090-0233(97)80020-2.

Fluegel-Dougherty, A. M., Cornish, T. E., O'Toole, D., Boerger-Fields, A. M., Henderson, L. O., Mills, K. W. (2013). Abortion and premature birth in cattle following vaccination with Brucella abortus strain RB51. Journal of Veterinary Diagnostic Investigation, 25(5), 630-5. doi: 10.1177/1040638713499570.

Gundelach, Y., Essmeyer, K., Telscher, M. K., Hoedemaker, M. (2009). Risk factors for perinatal mortality in dairy cattle: Cow and foetal factors, calving process. Theriogenology, 71(6), 901-9. doi: 10.1016/j.theriogenology.2008.10.011.

Gül, Y., Baykalır, B. (2013). Serum ß-carotene and vitamin a levels in spontaneous premature calves with respiratory distress syndrome. Kafkas Universitesi Veteriner Fakültesi Dergisi, 19(6): 1029-33. doi: 10.9775/kvfd.2013.9398.

Güzelbekteş, H., Coskun, A., Ok, M., Aydogdu, U., Sen, I. (2012). Prevalence of gastroesophageal reflux disease in premature calves. Journal of Veterinary Internal Medicine, 26(4), 1051-55. doi: 10.1111/j.1939-1676.2012.00934.x.

Irmak, K., Turgut, K. (2011). The evaluation of coagulation profiles in spontaneous premature calves with respiratory distress syndrome. Kafkas Universitesi Veteriner Fakültesi Dergisi, 17(2), 197201. doi: 10.1007/s11259-006-3258-8.

Johanson, J. M., Berger, P. J. (2003). Birth weight as a predictor of calving ease and perinatal mortality in Holstein cattle. Journal of Dairy Science, 86(11), 3745-55. doi: 10.3168/jds.S0022-0302(03)73981-2.

Karapınar, T., Dabak, M. (2008). Treatment of premature calves with clinically diagnosed respiratory distress syndrome. Journal of Veterinary Internal Medicine, 22(2), 462-6. doi: 10.1111/j.19391676.2008.0074.x.

Koterba, A., Madigan, J. E. (2009). Manifestations of diseases of the neonate. In P. S. Bradford (Eds.), Large Animal Internal Medicine (pp.455-66). 
Korkmaz, A. (2003). Respiratory distress syndrome. Turkiye Klinikleri Journal of Pediatric Science, 9(1), 18-24.

Kornmatitsuk, B., Franzén, G., Gustafsson, H., Kindahl, H. (2003). Endocrine measurements and calving performance of swedish red and white and swedish holştein dairy cattle with special respect to stillbirth. Acta Veterinaria Scandinavica, 44(1-2), 2133. doi: 10.1186/1751-0147-44-21.

Kültürsay, N., Tansuğ, N. (2000). Sürfaktan ve neonatal respiratuvar distres sendromunda ekzojen sürfaktan kullanımı. ADÜ Tıp Fakültesi Dergisi, 1(2), 47-52.

Lammoglia, M. A., Bellows, R. A., Grings, E. E., Bergman, J. W., Short, R. E., MacNeil, M. D., (1999). Effects of feeding beef females supplemental fat during gestation on cold tolerance in newborn calves. Journal of Animal Science, 77(4), 824-34. doi: $10.2527 / 1999.774824 x$.

Leclere, M., Lefebvre-Lavoie, J., Beauchamp, G., Lavoie, J. P. (2010). Efficacy of oral prednisolone and dexamethasone in horses with recurrent airway obstruction in the presence of continuous antigen exposure. Equine Veterinary Journal, 42(4), 316-21. doi: 10.1111/j.2042-3306.2009.00022.x.

Macfarlane, J., Walker, B. (2007). Pregnancy toxaemia in beef cattle. Primefact, 335, 1-3.

Mazzaferro, E. M. (2006). Inhalation therapy: New approaches to old diseases. Small Animal And Exotics: North American Veterinary Conference, USA, 20(1), 275-276.

Meyer, C. L., Berger, P. J., Koehler, K. J., Thompson, J. R., Sattler, C. G. (2001). Phenotypic treds in incidence of stillbirth for Holsteins in the United States. Journal of Dairy Science, 84(2), 515-23. doi: 10.3168/jds.S0022-0302(01)74502-X.

Morresey, P. R. (2008). How to deliver respiratory treatments to neonates by nebulization. AAEP Proceedings (54th) San Diego, CA, USA. 54, 520-26.

Ok, M. (2020). Prematüre (Günsüz) doğan buzağıların bakımı. H. Erdem, E. Çiftçi, K. Işık, M. Ü. Yorgancilar, C. Yaralı (Eds), Buzağı Sağlı̆̆ı ve Yetiştiriciliği. (pp. 44-48). Medisan Yayınevi

Ok M., Yıldız, R., Traş, B., Başpınar, N., Akar, A. (2020). Effect of nebulized formeterol, ipratropium bromid, and furosemid in combination with fluticasone propionate on arterial blood gases premature calves with respiratory distres syndrome. Jounal of Hellenic Veterinary Medical Society, 71(1), 2011-2018. doi: https://doi.org/10.12681/jhvms.22949

Ok, M., Güler, L., Turgut, K., Ok, U., Sen, I., Gündüz, K., Birdane, M. F., Güzelbekteş, H. (2009). The studies on the etiology of diarrhea in neonatal calves and determination of virulence gene markers of Escherichia coli strains by multiplex PCR. Zoonoses and Public Health, 56(2), 94-101. doi: 10.1111/j.18632378.2008.01156.x.

Ok, M., Birdane. F.M., Sen. I., Guzelbektes. H. (2000). Study on some blood biochemical parameters in premature calves. The Indian Veterinary Journal, 77(10), 859-61.

Ortatalı, M., Çiftçi, M. K. (1996). İnsan ve hayvanlarda akciğer surfaktan sistemi ve önemi. Veteriner Bilimleri Dergisi, 12(1), 117-21.
Ovalı, F. (2007). Solunum sikıntıs1 ve respiratuar distres sendromu. In T. Dağoğlu, \& F. Ovalı (Eds), Neonatoloji. (pp. 331-346).

Palmer, M. V., Cheville, F., Jensen, A. E. (1996). Experimental infection of pregnant cattle with the vaccine candidate brucella abortus strain RB51: pathologic, bacteriologic, and serologic findings. Veterinary Pathology, 33(6), 682-91. doi: 10.1177/030098589603300607.

Pekcan, S. (2012). Çocuklarda inhaler tedavi uygulamaları. Solunum, 14(2), 63-72.

Radostits, O. M., Gay, C. C., Hinchcliff, K. W., Constable, P. D. (2007). Veterinary medicine: a textbook of the diseases of cattle, sheep, goats, pigs and horses (10th ed.). Saunders Elsevier.

Robinson, N. E., Berney, C., Behan, A., Derksen, F. J. (2009). Fluticasone propionate aerosol is more effective for prevention than treatment of recurrent airway obstruction. Journal of Veterinary Internal Medicine, 23(6), 1247-53. doi: 10.1111/j.19391676.2009.0382.x.

Sahni, J., Phelps, S. J. (2011). Nebulized furosemide in the treatment of bronchopulmonary dysplasia in preterm infants. The Journal of Pediatric Pharmacology and Therapeutics, 16(1), 14-22.

Satar, M. (2004). Neonatal hipoglisemi ve hiperglisemi. Türkiye Klinikleri Journal of Pediatric Science, 2(7), 787-91.

Sen, I., Ok, M., Altunok, V., Çoşkun, A., Constable, P. D. (2009). Efficacy of oral rehydration therapy solutions containing sodium bicarbonate or sodium acetate in treating calves with naturally acquired diarrhea, moderate dehydration, and strong ion acidosis. Journal of the American Veterinary Medical Association, 234(7), 926-34. doi: 10.2460/javma.234.7.926.

Sheldon, I. M., Barrett, D. C., Boyd, H. (2004). The Postpartum Period. In A. H. Andrews (Eds.), Bovine Medicine Diseases and Husbandry of Cattle. (pp. 508527).

Traş, B., Yazar, E., Elmas, M. (2012). Veteriner Ilaç (1th ed.).

Uystepruyst, C., Coghe, J., Dorts, T., Harmegnies, N., Delsemme, M. H., Art, T., Lekeux, P. (2002). Sternal recumbency or suspension by the hind legs immediately after delivery improves respiratory and metabolic adaptation to extra uterine life in newborn calves delivered by caesarean section. Veterinary Research, 33(6), 709-24. doi: 10.1051/vetres:2002051.

Warner, A. E. (2009). The Respiratory System In B. P. Smith (Eds), Large Animal Internal Medicine (pp. 489545).

Yıldı,, R., Ok, M., Ider, M., Akar, A., Nasari, A., Koral, E. (2019). The changes in biomarkers for necrotising enterocolitis in premature calves with respiratory distress syndrome. Veterinarni Medicina, 64(10), 44047. https://doi.org/10.17221/37/2019-VETMED

Yıldız, R., Ok, M., Ider, M., Aydoğdu, U., Naseri, A., Parlak, K., Gülersoy, E. (2018). Evaluation of intestinal damage biomarkersin calves with atresia coli. Journal of Veterinary Research, 62(3), 379-84. doi: 10.2478/jvetres-2018-0054 
Yıldız, R., Aydogdu, U., Guzelbektes, H., Coskun, A., Sen, I. (2017) Venous lactate, $\mathrm{pH}$ and partial pressure of carbon dioxide levels as prognostic indicators in 110 premature calves with respiratory distress syndrome. Veterinay Record, 180(25), 611-16. doi: 10.1136/vr.103730.

Yıldız, R., Ok, M. (2017). Clinical efficacy of combinations of nebulised fluticasone, salbutamol and furosemide on lung function in premature calves with respiratory distress syndrome. Veterinarni Medicina, 62(10), 541-52. https://doi.org/10.17221/34/2017VETMED

Yurdakök, M. (1991). Respiratuvar distres sendromu ve ventilatör tedavisinin ilkeleri. Katkı Pediatri Dergisi Neonatal Respiratuvar Distres Özel Sayısı, 299-370.

Zerbe, H., Zimmermann, D. K., Bendix, A. (2008). Neonatal asphyxia in calves: diagnosis, therapy and prophylaxis. Tierarztl Prax Ausg $G$ Grosstiere Nutztiere, 36(3), 163-69. 